\title{
STANDART PELAYANAN PUBLIK DI ERA TRANSISI NEW NORMAL
}

\author{
Abd. Rohman ${ }^{1}$, Dewi Citra Larasati ${ }^{2}$ \\ ${ }^{1,2}$ Program Studi Administrasi Publik, Universitas Tribhuwana Tunggadewi, Malang \\ Email : rohmanch93@yahoo.com; citralarasati311@gmail.com
}

\begin{abstract}
Abstrak: Perubahan nomenklatur Badan Pelayanan Pajak Daerah menjadi Badan Pendapatan Daerah (Bapenda) Kota Malang di awal tahun 2020, menyebabkan bertambahnya beban kerja yang harus dijalankan. Demikian juga saat pandemi covid-19 muncul menuntut Bapenda harus baradaptasi dengan tatanan new normal. Dimana Bapenda harus memberikan pelayanan terbaik dengan tetap mematuhi protokol kesehatan yang ada. Pendekatan yang digunakan adalah kualitatif, teknik pengumpulan data dengan interview, observasi dan dokumentasi. Keabsahan data menggunakan triangulasi sumber. Hasil penelitian menunjukkan bahwa Bapenda Kota malang telah menjalankan standart pelayanan dengan menggunakan protokol kesehatan. Upaya yang dilakukan adalah dengan mengurangi jumlah pegawai yang bertugas di loket pelayanan, mengalihkan pelayanan pelaporan serta konsultasi pajak melalui online, masyarakat dibebaskan dari biaya dalam mengakses pelayanan, menyediakan informasi produk layanan dalam bentuk buku atau menanyakan langsung kepada petugas yang ada di ruang tunggu, pemenuhan sarana dan prasarana pelayanan sesuai protokol kesehatan serta menempatkan petugas di lokat pelayanan sesuai dengan kompetensi yang dimiliki. Hasil penelitian ini juga mengungkapkan kurangnya kesadaran wajib pajak yang membutuhkan pelayanan dalam mentaati protokol kesehatan.
\end{abstract}

Kata Kunci: Standart Pelayanan; Manajemen Pelayanan; New Normal

Abstract: Changing the nomenclature of the Regional Tax Service Agency to become the Regional Revenue Agencies of Malang City in early 2020 caused increasing in the workload that must be carried out. So as, when the Covid-19 pandemic emerged, Bapenda had to adapt to the new normal order. Bapenda must provide the best service while adhering to existing health protocols. Researchers used a qualitative approach with data collection techniques through interviews, observation and documentation. Data validity used source triangulation. The results showed that Bapenda of Malang City had implemented service standards by using health protocols. Efforts are being made to reduce the number of employees on duty at service counters, divert reporting services and tax consultation via online, the public is exempted from fees in accessing services, providing service product information in bookform or asking directly to officers in the waiting room, fulfillment service facilities and infrastructure according to health protocols and placing officers at service locations according to their competencies. Meanwhile, the obstacle faced is the awareness of taxpayers who need services to comply with health protocols.

Keywords: Service Standards; Service Management; New Normal 


\section{PENDAHULUAN}

Pandemi Covid-19 yang terjadi saat ini menuntut perubahan dalam birokrasi pelayanan publik. Perubahan birokrasi tersebut terjadi dalam dua demensi, yakni demensi organisasi dan sistem kerja. Pada demensi organisasi telah terjadi perubahan dari semula dilakukan dengan cara normal, dituntut untuk beralih pada model birokrasi new normal. Sementara perubahan dalam sistem kerja disodorkan dua pilihan, yakni work form home (WFH) dan tetap bekerja di kantor dengan memperhatikan dan menjalankan protokol kesehatan yang telah ditentukan (Taufik \& Warsono, 2000). Salah satu dampak besar pandemi Covid-19 bagi masyarakat Indonesia adalah bidang pelayanan publik. Indonesia perlu penggunaan model integrasi vertikal dan horizontal dengan mengahdirkan network service layanan satu pintu yang membutuhkan transformasi pelayanan publik dari paradigma administrasi publik lama ke pelayanan publik baru. Selain itu, dibutuhkan juga harmoniasi antar lembaga pemerintah, agar tidak terjadi gesekan dan konflik yang berdampak pada penurunan kualitas pelayanan kepada masyarakat (Lumbanraja, 2020).

Kualitas pelayanan kepada masyarakat harus tetap terjaga. Pemerintah dituntut tetap memberikan pelayanan terbaik meskipun di lain sisi harus menjalankan himbauan protokol kesehatan demi keselamatan bersama, baik penyedia maupun penerima layanan dengan menerapkan social distancing dan physical distancing. Kondisi ini mendorong Pemerintah Indonesia mengeluarkan kebijakan terbaru mengenai new normal atau Pola Hidup Baru. Kebijakan ini tertuang dalam Keputusan Menteri Dalam Negeri (Kepmendagri) No. 440-830 Tahun 2020 tentang Pedoman Tatanan Normal Baru bagi Pemerintah Daerah (Pemda) dan Aparatur Sipil Negara (ASN) di lingkungan Kementerian Dalam Negeri (Kemdagri). Respon Pemerintah terkait kondisi tersebut juga tertuang dalam Surat Edaran Menteri Pendayagunaan Aparatur Negara dan Reformasi Birokrasi (PANRB) No. 58/2020 tentang Sistem Kerja Pegawai ASN dalam Tatanan Normal Baru. Dalam surat edaran ini menegaskan penyesuaian pola kerja agar budaya kerja yang adaptif dan berintegritas dapat terwujud.

Pemerintah kota Malang dalam merespon kondisi tersebut dengan mengeluarkan kebijakan yang dituangkan dalam Surat Edaran (SE) Wali Kota Malang No. 20 Tahun 2020 tentang Tatanan Normal Baru Produktif dan Aman Covid-19 bagi Aparatur Sipil Negara dan Karyawan/Karyawati BUMD. Esensi dari kebijakan ini adalah tetap menjalankan aktivitas normal, akan tetapi tetap dengan menerapkan protokol kesehatan yang sangat ketat demi mencegah penularan virus melalui kluster-kluster baru. Kebijakan ini menuntut semua yang terkait dengan pelayanan melakukan penyederhanaan di segala lini aktivitasnya, seperti: melakukan penyederhanaan SOP (Standard Operating Procedure) melalui pemanfaatan teknologi informasi serta adanya pemberlakuan WFH (Work from Home) dan WFO (work from office). Di sini pegawai tidak perlu ada di kantor secara fisik, namun masih tetap terhubung melalui pemanfaatan Teknologi Informasi dan Komunikasi (TIK). Demikian juga pelayanan konsultasi dan pengaduan dilakukan secara online, lebih mengoptimalkan media publikasi sebagai sarana sosialisasi, serta melakukan pelayanan secara offline dengan menggunakan standar protokol kesehatan yang ditetapkan oleh Kementerian Kesehatan. 
Pelayanan publik di era new normal dengan menerapkan kebijakan yang telah ditetapkan, akan berdampak terhadap akses pelayanan kepada masyarakat. Hal ini akan mengurangi intensitas pertemuan antara pemberi dan penerima layanan. Kondisi seperti ini, harus dijadikan sebagai sebuah momentum positif dalam mengoptimalkan pelayanan publik, yang awalnya dilakukan dengan tatap muka kemudian beralih ke sistem online menggunakan tekhnologi informasi. Tentunya peralihan ini juga harus diikuti dengan perubahan mindset masyarakat dengan memberikan sosialisasi ataupun edukasi supaya muncul kesadaran serta pemahaman sehingga dapat menghasilkan output yang efektif dan efisien.

Pemerintah kota Malang memberlakukan Pembatasan Sosial Berskala Besar (PSBB) satu kali putaran saja, selanjutnya pemerintah kota Malang mulai menerapkan masa transisi menuju new normal atau adaptasi tatanan kehidupan baru. Masa transisi ini, bukanlah masa yang mudah untuk dijalani. Karena Pemkot Malang harus bekerja ekstra keras memenuhi sarana dan prasarana yang berhubungan dengan protokol kesehatan. Baik yang ada di Kantor Pemerintahan maupun di sarana umum. Beberapa angaran mengalami pemangkasan dan dialokasikan (realokasi dan refocusing) untuk penanganan pandemi ini. Selain itu, Pemkot Malang juga harus berhadapan dengan mindset masyarakat yang masih abai terhadap protokol kesehatan. Padahal masa transisi ini yang terpenting adalah pemahaman masyarakat terhadap esensi bahwa pada new normal ini merupakan penerapan protokol kesehatan dengan lebih ketat dan disiplin. Namun faktanya, mindset masyarakat berbeda dengan apa yang diharapkan. Masyarakat secara umum masih beranggapan bahwa new normal semua sudah normal seperti sedia kala.

Kondisi ini menjadi tantangan tersendiri bagi Pemkot Malang terutama ketika masyarakat yang membutuhkan pelayanan administrasi, pelayanan barang publik maupun jasa publik datang ke kantor/dinas/badan di lingkungan Pemkot Malang. Pemkot Malang harus tetap memberikan pelayanan prima namun tidak mengesampingkan protokol kesehatan sekaligus harus mampu mengedukasi masyarakat dan merubah mindset yang salah tersebut. Penilitian ini dilakukan pada Badan Pendapatan Daerah (Bapenda) Kota Malang. Pada awal tahun 2020, Badan Pelayanan Pajak Daerah (BP2D) Kota Malang berganti nomenklatur menjadi Badan Pendapatan Daerah (Bapenda) Kota Malang. Dengan adanya perubahan tersebut, tugas Bapenda semakin bertambah. Jika dulu BP2D hanya menangani pelayanan terhadap masyarakat dan melakukan pemungutan pajak daerah, saat ini Bapenda mendapatkan tambahan tugas dan fungsi koordinasi serta akuntansi pendapatan asli daerah (PAD) Kota Malang yang meliputi pemungutan dan pembukuan pajak daerah, semua retribusi daerah dan pendapatan asli daerah lain yang sah seperti sewa aset dan lain-lain. Dengan beban tugas yang semakin besar tersebut maka, intensitas pelayanan terhadap masyarakat juga makin bertambah apalagi di era transisi new normal seperti saat ini.

Dari itu, aparatur pemerintah dituntut untuk melakukan perubahan pola dalam memberikan pelayanan kepada masyarakat dengan meningkatkan kemampuan manajerial dan pengambilan keputusan, kecepatan, kelincahan, adaptabilitas serta penyesuaian teknologi yang digunakan dan SDM yang dibutuhkan (Yulianto, 2020). Namun demikian, apabila ditinjau dari perspektif konsep telecommuting, skema work form home, network service atau 
dengan sebutan lainnya sebenarnya merupakan hal yang lumrah dalam dunia kerja dan perencanaan kota. Konsep WFH ini sebenarnya sudah mulai diterapkan sebagian lembaga/organisasi pada kondisi normal dan bukan karena adanya pandemi Covid-19. Namun pada saat ini masyarakat secara umum dituntut lebih mengenal WFH ini serta langkahlangkahnya. Pada saatnya nanti konsep ini akan menjadi bagian tatanan baru (new normal) dari kehidupan sehari-hari sehingga telecommuting menjadi suatu keniscayaan (Mungkasa, 2020).

Manajemen pelayanan menurut Mukarrom \& Laksana (2015:80) merupakan proses penerapan ilmu dan seni untuk menyusun rencana dalam mengimplementasikan rencana, mengkoordinasikan, dan menyelesaikan aktivitas-aktivitas pelayanan demi tercapainya tujuan pelayanan. Sedangkan menurut Santosa pelayanan publik merupakan pemberian jasa, baik oleh pemerintah, pihak swasta atas nama pemerintah, atau pihak swasta kepada masyarakat (Rohman \& Hardianto (2019:104). Undang-Undang Republik Indonesia Nomor 25 tahun 2009 tentang Pelayanan Pubik, menegaskan bahwa pelayanan publik adalah kegiatan atau rangkaian kegiatan dalam rangka pemenuhan kebutuhan pelayanan sesuai dengan peraturan perundang-undangan bagi setiap warga negara dan penduduk atas barang, jasa, dan/atau pelayanan administratif yang disediakan oleh penyelenggara pelayanan publik.

Dalam menjalanakan pelayanan ada ukuran yang harus ditaati oleh pemberi layanan yang biasa dikenal dengan standar layanan publik. Menurut Zainal, dkk., standar pelayanan publik meliputi: 1) prosedur pelayanan, 2) waktu penyelesaian. 3) biaya pelayanan, 4) produk pelayanan, 5) sarana dan prasarana, dan 6) kompetensi petugas pemberi pelayanan. Selain itu, terdapat faktor yang menjadi pendukung dalam mewujudkan pelayanan prima, yakni kesadaran, aturan, organisasi-organisasi publik, pendapatan dan kesejahteraan, kemampuan dan ketrampilan pegawai serta sarana dan prasarana yang memadai. Namun faktor tersebut dapat juga menjadi penghambat jika hal tersebut dijadikan resisten dalam pelayanan (Rohman \& Hardianto, 2019:117-118). Oleh karena itu, penelitian ini ingin mengetahui bagaimana manajemen pelayanan publik di Bapenda kota Malang yang meliputi standart pelayanan yang dilakukan di masa transisi new normal serta permasalahan yang dihadapi.

\section{METODE PENELITIAN}

Peneliti menggunakan pendekatan kualitatif dalam untuk mengurai permasalahan yang ada. Dengan melakukan pendekatan studi kasus di Badan Pendapatan Daerah (Bapenda) kota Malang, peneliti ingin mengetahui bagaimana pelaksanaan manajemen pelayanan di masa pandemi covid-19. Untuk mendapatkan data yang dibutuhkan, peneliti melakukan pengumpulan data melalui interview dan pengumpulan data melalui dokumen. Peneliti melakukan interview dengan beberapa informan tanpa menggunakan interview guide, sehingga interview yang dilakukan bersifat bebas. Dengan interview yang bersifat bebas ini, peneliti bisa mendapatkan informasi dan data sebanyak-banyaknya karena penelitian yang dilakukan ini tergolong masih baru. Selain melakukan interview, peneliti juga melakukan sinkronisasi dengan dokumen yang ada di Bapenda seperti foto, laporan, grafik, serta sumbersumber berita yang ada di media online. Setelah memperoleh data melalui interview dengan 
beberapa informan dan melakukan sinkronisasi dengan dokumen yang ada, peneliti melakukan analisis data secara terus menerus hingga tuntas secara interaktif. Uji keabsahan data yang digunakan peneliti adalah triangulasi sumber, yakni mengecek kembali data-data yang digunakan melalui sumber yang berbeda (Sugiyono, 2018: 247).

\section{HASIL DAN PEMBAHASAN}

\section{Standart Pelayanan di Masa Transisi New Normal}

Bapenda Kota Malang dengan nomenklatur baru mempunyai tugas pokok dan fungsi yang semakin berat. Bapenda dituntut mampu melahirkan inovasi-inovasi terutama dalam melakukan penyelenggaraan pelayanan publik. Penyelenggaraan publik tidak bisa dilepaskan dari standar pelayanannya. Standar inilah yang kemudian menjadi tolok ukur pelayanan yang berfungsi sebagai pedoman penyelenggaraan pelayanan publik. Pedoman ini berfungsi sebagai acuan bagi pelaksana pelayanan publik dan para pengguna pelayanan dalam memenuhi dan memperoleh hak serta kebutuhan dasarnya. Standar pelayanan juga diperlukan dalam upaya menilai efektivitas pelayanan yang diberikan oleh Bapenda Kota Malang serta mengukur kepuasan masyarakat saat mengakses pelayanan. Penilaian itulah yang kemudian bisa dijadikan landasan untuk memperbaiki kualitas pelayanan agar penyelenggaraannya semakin berkualitas, mudah, cepat, terjangkau dan terukur. Sekurang-kurangnya Standar pelayanan tersebut wajib disusun, ditetapkan dan diterapkan sehingga diketahui oleh masyarakat luas yang mengakses pelayanan. Berikut ini komponen wajib standar pelayanan yang harus ada pada unit manajemen pelayanan publik:

Prosedur Pelayanan dan Jangka Waktu Layanan, adalah tata cara yang dibakukan oleh pemberi pelayanan terhadap penerima pelayanan publik. Prosedur pelayanan adalah proses yang harus dijalani seorang pelanggan untuk mendapatkan pelayanan yang diperlukan. Bapenda Kota Malang berdasarkan tugas pokok dan fungsinya memberikan layanan pajak daerah meliputi : a) pendataan obyek dan wajib pajak di kota Malang, b) monev yang berhubungan dengan objek pajak di kota Malang, c) penerimaan dan pendistribusian formulir pendaftaran wajib pajak, d) penerimaan pengajuan penerbitan Nomor Pokok Wajib Pajak Daerah (NPWPD), e) layanan mengenai penetapan SPPT, SKPD, SKPDKB, SKPDLB, dan SKPDN, f) pendistribusian SSPD, SPPT dan SKPD kepada Wajib Pajak, g) pemungutan Pajak Daerah dan Pajak Daerah lain sesuai ketentuan Daerah, h) layanan tentang permohonan pengurangan dan penundaaan denda Pajak Daerah, i) layanan keberatan atas ketetapan besaran Pajak Daerah, j) Layanan untuk pemungutan dan penagihan Pajak Daerah, k) penerimaan pengajuan keberatan/perubahan/mutasi Pajak Daerah dari Wajib Pajak, l) layanan penyelesaian sengketa Pajak Daerah atau Pajak Daerah lainnya, m) layanan data dan informasi potensi Wajib Pajak Daerah.

Pelayanan tersebut dilayani oleh Bapenda Kota Malang dengan membuka pelayanan loket untuk memudahkan masyarakat Kota Malang yang hendak mengakses pelayanan perihal pelayanan Pajak Daerah. Pelayanan loket Pajak Daerah ini dapat ditemui oleh masyarakat di Perkantoran Terpadu Gedung B First Floor, JL. Mayjend Sungkono, Arjowinangun, Kec. Kedungkandang, Kota Malang, Jawa Timur 65132. Pelayanan Loket di Bapenda Kota Malang 
terdiri dari dua loket utama yaitu 1) Loket di sebelah timur yaitu loket yang menangani PBB dan BPHTB dan 2) Loket sebelah barat yang melayani Pajak Daerah Lain, meliputi Pajak Resto, Pajak Hotel, Pajak Parkir, Pajak Hiburan, Pajak Air Tanah dan Pajak Penerangan Jalan Non PLN. Berikut ini adalah dokumentasi mengenai loket pelayanan:

Gambar 1. Loket PBB dan BPHTB

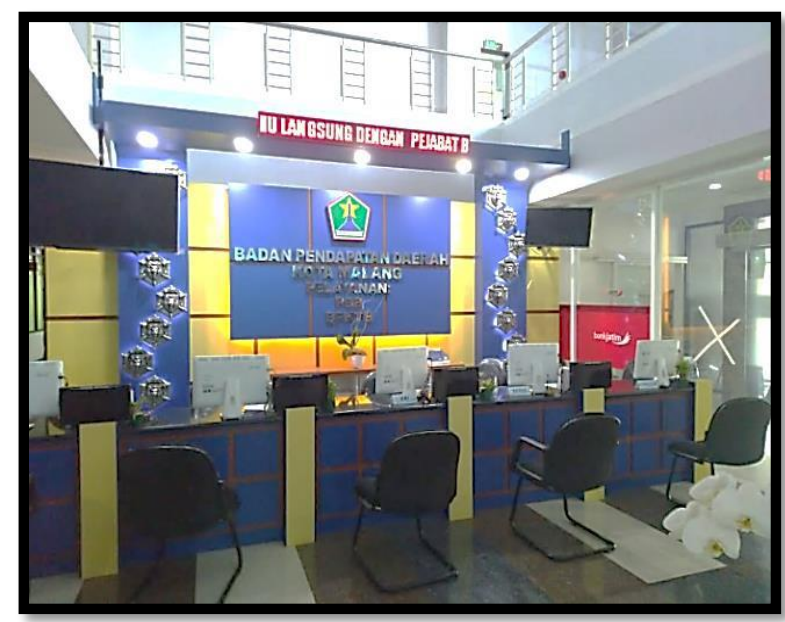

Gambar 2. Loket Pelayanan Pajak Daerah Lain

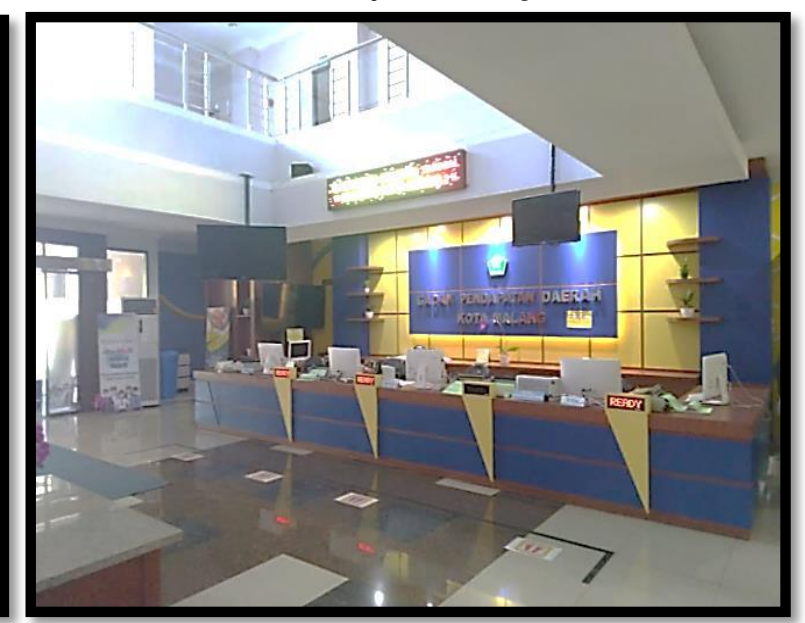

Sumber: Dokumentasi Penelitian, Juni 2020

Berdasarkan informasi dari informan peneliti di Bapenda dijelaskan bahwa dengan berjalannya waktu, rate untuk pelayanan Pajak reklame semakin besar. Karena arsip untuk pajak reklame merupakan arsip hidup yang mana dibutuhkan sewaktu-waktu, berbeda halnya dengan pelayanan Pajak Daerah lainnya yang mana sekali pengurusan selesai. Pajak reklame, selain pengurusan pajak juga ada pengurusan jasa bongkar yang biasa disebut jambong. Jambong ini dibayarkan bersamaan dengan pajak reklame, namun jika pemilik usaha menginginkan untuk membongkar reklamenya sendiri, maka jambong ini bisa diambil. Pelayanan Pajak reklame ini sangatlah banyak dari yag kecil hingga yang besar sehingga pelayanan yang awalnya bergabung dengan loket pelayanan PBB dan BPHTB, maka dibuatkan loket tersendiri, supaya lebih mengefisienkan waktu yang ada. Berikut ini adalah dokumentasi loket pelayanan reklame di Bapenda Kota Malang:

\section{Gambar 3. Loket Pelayanan Reklame}

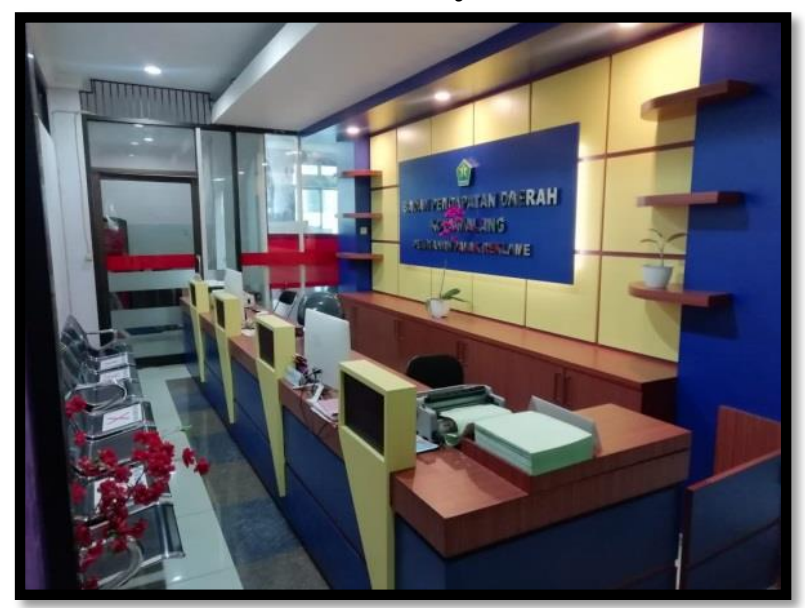

Sumber: Dokumentasi Penelitian, Juni 2020 
Sebelum adanya pandemi, pegawai pelayanan yang ditempatkan di masing-masing loket berkisar 3-6 orang. Namun sejak terjadinya pandemi covid-19, pegawai yang bertugas di loket dikurangi separuh kapasitas dengan mematuhi standart protokol kesehatan yaitu physical distancing (jaga jarak). Dimana saat pandemi, pegawai yang melakukan pelayanan loket PBB dan BPHTB hanya ditugaskan 2-3 orang dari yang biasanya 5 orang. Pegawai di loket Pajak Daerah Lain juga hanya 3-4 orang dari yang biasanya 6 orang. Begitupula dengan loket reklame, biasanya 3-4 orang sekarang hanya 2 orang (1 pegawai melayani masyarakat dan 1 pegawai lainnya mengurus berkas).

Para petugas loket diwajibkan menggunakan masker dan dibekali handsanitizer, begitu juga dengan pengunjung yang akan mengakses pelayanan di Bapenda pun diatur dengan protokol kesehatan yang ketat. Selain itu, untuk pelaporan pajak bulanan atau tahunan dan konsultasi perpajakan yang biasanya dilakukan dengan datang ke kantor dan tatap muka, sejak adanya pandemi Bapenda melakukan pelayanan secara online. Pelaporan dan konsultasi perpajakan bisa melalui telpon di nomer (0341) 2993188 atau (0341) 751532 atau bisa juga melalui WA kantor Bapenda 081255455955 dan mengirimkan faksimile ke nomer (0341) 2993010 atau melalu email bppd@malangkota.go.id. Pelayanan konsultasi yang sifatnya berat dan perlu tindakan khusus seperti : sengketa, keberatan, dan keringanan pajak.

Bapenda dalam memberikan pelayanan terhadap masyarakat di era transisi new normal saat ini sama seperti jam buka kantor yaitu Senin sampai dengan Kamis pukul 08.00-16.00 dan Jum'at pukul 07.30-15.00. Sesuai dengan Surat edaran Walikota Malang Nomor 24 Tahun 2020 tentang perubahan atas surat edaran Walikota Malang Nomor 20 tahun 2020 tentang tatanan normal baru produktif dan aman covid-19 dijelaskan bahwa adanya Shift setiap harinya dengan cara bergiliran supaya tetap dapat memenuhi target kinerja setiap harinya. Namun, di Bapenda aturan ini tidak diberlakukan, dikarenakan beban kinerja yang sangat tinggi dan tuntutan pelayanan kepada masyarakat. Dengan mematuhi protokol kesehatan dan disiplin kerja, pegawai Bapenda baik ASN maupun non ASN bekerja sesuai jam kantor untuk memberikan pelayanan terbaik bagi masyarakat.

Pelayanan terbaik untuk masyarakat ini adalah wujud pemberian pelayanan prima kepada masyarakat. Untuk menunjang jalannya pelayanan yang baik, setiap pelayanan selalu ada mekanisme dan prosedurnya. Supaya masyarakat bisa memenuhi segala persyaratan yang dibutuhkan untuk pengurusan berkas, dan pegawai Bapenda di loket pelayanan juga bisa memproses dengan cepat. Ini adalah suatu bentuk simbiosis mutualisme antara pemberi layanan dan penerima layanan publik. Mekanisme pelayanan tersebut secara umum telah ada SOPnya, sebagaimana gambar alur pelayanan di bawah ini: 
Gambar 4. Alur Pelayanan di Bapenda Kota Malang

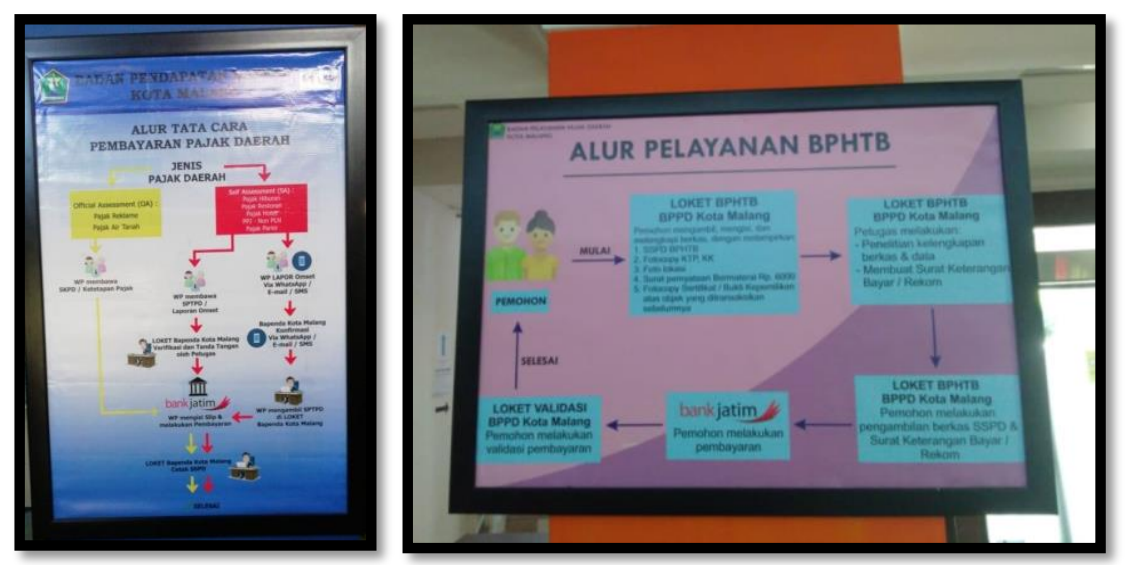

Sumber: Dokumentasi Penelitian, Juni 2020

Dokumentasi tersebut diatas adalah bentuk alur pelayanan normal sebelum adanya pandemi. Namun setelah adanya pandemi, Bapenda melakukan relaksasi SOP dimana ada beberapa aturan protokol kesehatan yang ketat yang harus dilalui oleh masyarakat yang datang di kantor Bapenda Kota Malang. Orang datang (Wajib Pajak/WP) saat datang sudah ditanya oleh satpam atau pegawai Tenaga Penunjang Operasinal Kantor (TPOK) untuk diarahkan. Biasanya masyarakat yang datang akan diberikan beberapa arahan sebagaimana berikut yaitu 1) apa yang akan diurus, satpam akan memproses nomer antrian dan memberi arahan nantinya akan ke loket mana, akan diberi tahu juga untuk pembayaran tidak di lakukan di kantor Bank Jatim di dalam gedung karena untuk pembayaran dilakukan di luar untuk menghindari penumpukan. Bapenda dan Bank Jatim telah menyediakan Mobil $e$-tax Bapenda dan mobil pelayanan dari Bank Jatim di halaman depan Bapenda. 2) masyarakat yang akan mengurus di cek suhu tubuhnya, 3) diarahkan untuk ke bilik sico dan cuci tangan menggunakan air mengalir di tempat yang sudah disediakan. Kemudian 4) diarahkan untuk duduk ke tempat duduk yang sudah disediakan dan diatur sesuai dengan protokol kesehatan.

Mekanisme pelayanan PDL (Pajak Daerah Lain) yang ada di kantor Bapenda hanya sebatas untuk penerbitan Surat Ketetapan Pajak Daerah (SKPD) kemudian laporan omzet, setelah penerbitan SKPD, Wajib Pajak (WP) melakukan pembayaran ke bank Jatim, dan bukti pembayarannya akan mendapat stempel pengesahan di kantor Bapenda. Berbeda dengan pelayanan di loket PBB dan BPHTB, petugas pelayanan di loket harus mengetahui terlebih dahulu apa yang menjadi permasalahan dari setiap WP apakah itu terkait kesesuaian dokumen BPHTB, kelengkapan berkas BPHTB, pembetulan SPPT, pengurangan PBB, perubahan luasan dan lain-lain. Permasalahan inilah yang membuat pelayanan di loket PBB dan BPHTB sedikit lama. Semua tergantung permasalahan yang dibawa WP ke loket.

Biaya/Tarif, setiap pelayanan yang diakses akan memberikan konsekwensi dengan adanya biaya/tarif/harga yang akan dibayar. Oleh karena itu, sebagai upaya untuk mencegah timbulnya pungutan secara ilegal oleh oknum yang kurang bertanggung jawab, maka seharusnya organisasi penyelenggara pelayanan publik wajib memberitahukan besaran biaya yang harus dikeluarkan oleh masyarakat. Bahkan jika layanan yang diberikan memang 
diperuntukkan secara cuma-cuma, maka penyelenggara layanan publik wajib memampang kata "GRATIS" di unit pelayanannya. Dengan begini, maka bisa menekan potensi penyimpangan seperti adanya pungutan liar (pungli).

Bapenda Kota Malang termasuk dalam jajaran Organisasi Perangkat Daerah (OPD) di Zona Integritas Anti Korupsi. OPD ini sedang berbenah untuk naik tingkat menjadi Wilayah Bebas dari Korupsi (WBK) dalam rangka mewujudkan Wilayah Birokrasi Bersih dan Melayani (WBBM). Bapenda terus melakukan inovasi. Konsekuensi dari Zona Integritas Anti Korupsi adalah adanya komitmen untuk memberikan pelayanan yang totalitas dan menjadikan instansi birokrasi yang bersih. Sehingga semua pelayanan yang diakses di Kantor Bapenda Kota Malang bersifat gratis atau tidak dipungut biaya. Hal ini secara implementasi, pelayanan gratis ini telah berjalan dengan sangat baik. Bahkan untuk memberikan informasi kepada para pengguna layanan, di Bapenda banyak terpampang banner mengenai penjelasan Zona Integritas Anti Korupsi dari area depan Kantor Bapenda hingga di sekitar loket pelayanan. Hal ini juga dapat dilihat dari beberapa hasil dokumentasi yang diperoleh dari para informan sebagaimana berikut:

\section{Gambar 5. Banner Informasi mengenai Zona Integritas}

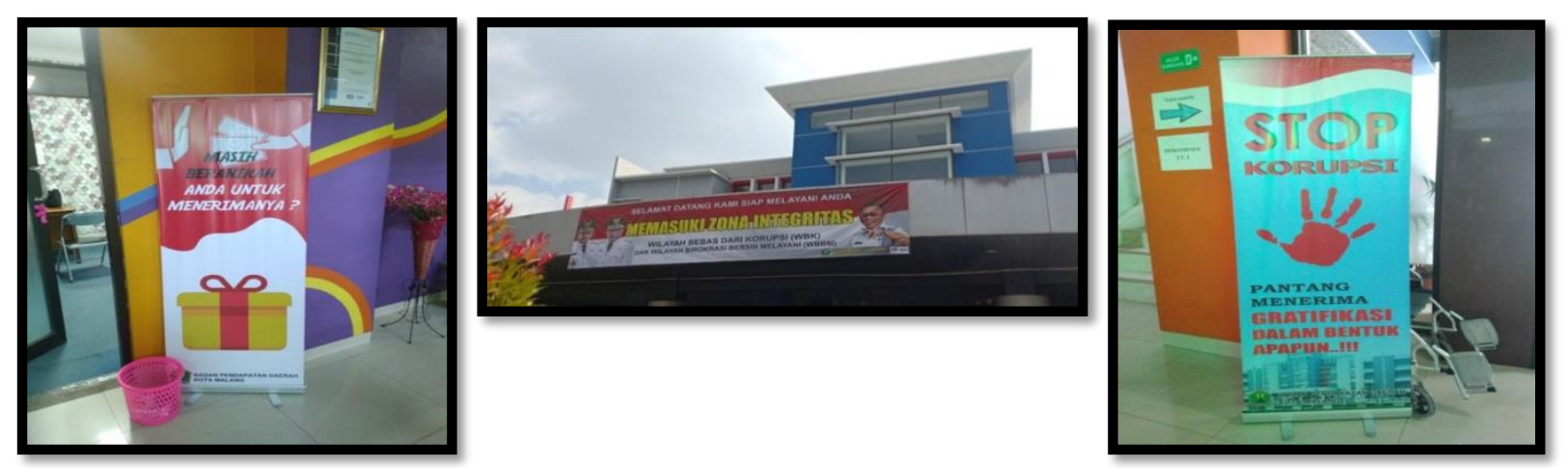

Sumber: Dokumentasi Penelitian, Juli 2020

Produk Pelayanan, merupakan hasil pelayanan yang akan diterima pengguna layanan yang mengakses pelayanan dengan ketentuan-ketentuan yang telah ditetapkan. Produk pelayanan yang bisa diperoleh adalah bentuk pelayanan jasa dan pelayanan administrasi mengenai perpajakan daerah. Produk pelayanan ini semacam menu yang ditawarkan oleh penyedia pelayanan dalam hal ini Bapenda Kota Malang. Untuk memilih produk pelayanan yang ditawarkan disana masyarakat bisa melihat buku panduan pelayanan pajak daerah yang mana bisa bisa ditemui di area pelayanan atau menanyakan langsung kepada petugas yang ada di ruang tunggu. Produk pelayanan yang dilayani oleh Bapenda meliputi PBB, BPHTB, Pajak Daerah Lain (PDL) seperti pajak resto, pajak hotel, pajak parkir, pajak hiburan, pajak reklame, pajak air tanah, dan PPJ non PLN. 
Gambar 6. Buku Produk Layanan tentang Panduan Layanan Pajak Daerah
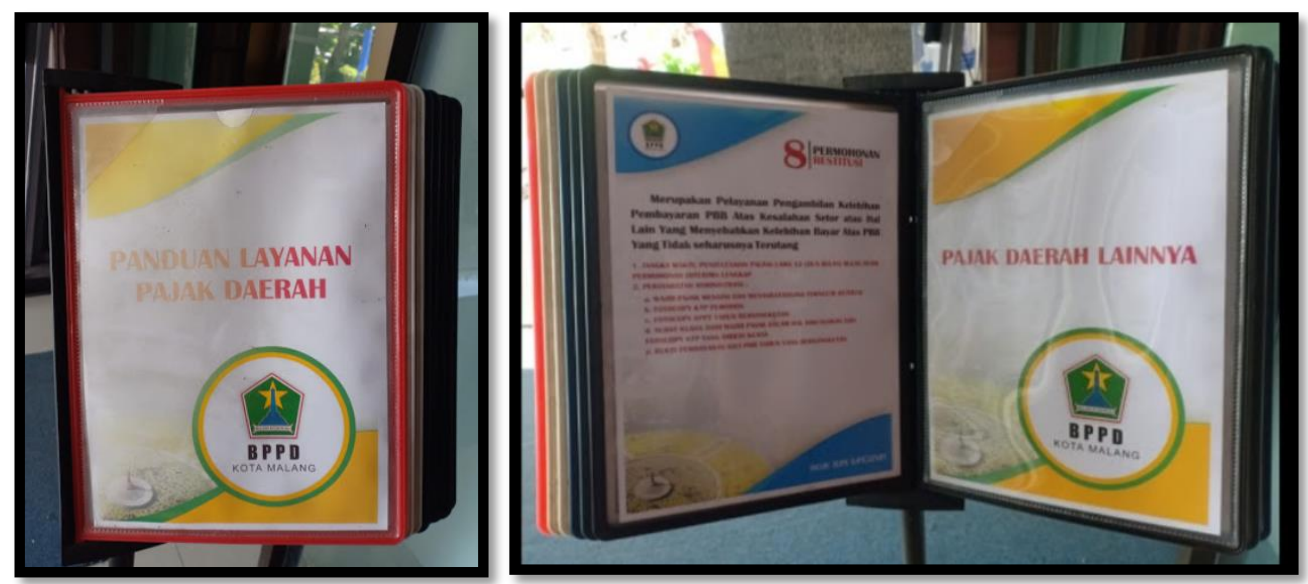

Sumber: Dokumentasi Penelitian, Juli 2020

\section{Gambar 7. Pengguna Layanan Menanyakan Kepada Petugas Mengenai Layanan}

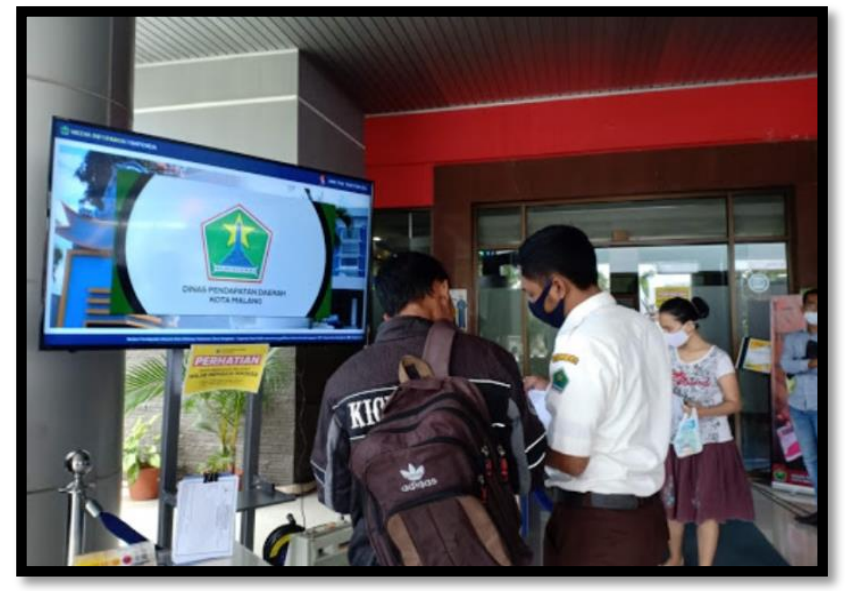

Sumber: Dokumentasi Penelitian, Juli 2020

Sarana, Prasarana atau Fasilitas. Kantor yang memberikan pelayanan harus didukung dengan sarana dan prasarana yang berkualitas serta memadai. Hal ini dilakukan supaya pengguna layanan yang datang ke Bapenda Kota Malang merasa nyaman saat mengakses pelayanan di Bapenda. Itulah mengapa sarana dan prasarana termasuk dalam salah satu indikator standar manajemen pelayanan publik. Beberapa sarana dan prasarana yang telah disediakan oleh Bapenda Kota Malang adalah 1) Tempat Parkir yang luas dan bebas dari biaya parkir, 2) Ruang Tunggu, 3) Ruang Laktasi, 4) Zona bermain anak (playgrund) 5) Fasilitas difable (kursi roda, dan sebagainya) 6) Snack dan Coffe and tea maker 7) Toilet 8) Mobil e-tax dan tentunya ruang pelayanan yang nyaman ber-AC serta ditunjang dengan kesediaan komputer dan perlengkapan lainnya yang menunjang pelayanan.

Sebelum pandemi terjadi, sarana dan prasarana di Bapenda Kota Malang sudah terbilang sesuai dengan standar pelayanan. Sehingga ketika pandemi terjadi dan adanya transisi menuju new normal. Bapenda tinggal menyesuaikan dengan protokol kesehatan yang 
ada. Seperti penambahan wastafel, penyediaan handsanitizer, bilik SiCo, thermalgun (alat tembak suhu tubuh), zona anakpun tidak digunakan dan kursi ruang tunggu diletakkan di luar dengan memperhatikan penerapan physical distancing. Penyemprotan disinfektan dilakukan sehari dua kali yaitu sebelum pelayanan dibuka dan setelah pelayanan selesai. Hal ini sebagai bentuk kenyamanan pelayanan tapi tetap menerapkan protokol kesehatan yang ketat. Berikut ini adalah beberapa dokumentasi sarana dan prasarana yang ada di Bapenda Kota Malang menghadapi transisi new normal sebagaimana berikut:

\section{Gambar 8. Penyemprotan Disinfektan, Pengecekan Suhu Tubuh dan Pengumuman} Area Bermasker
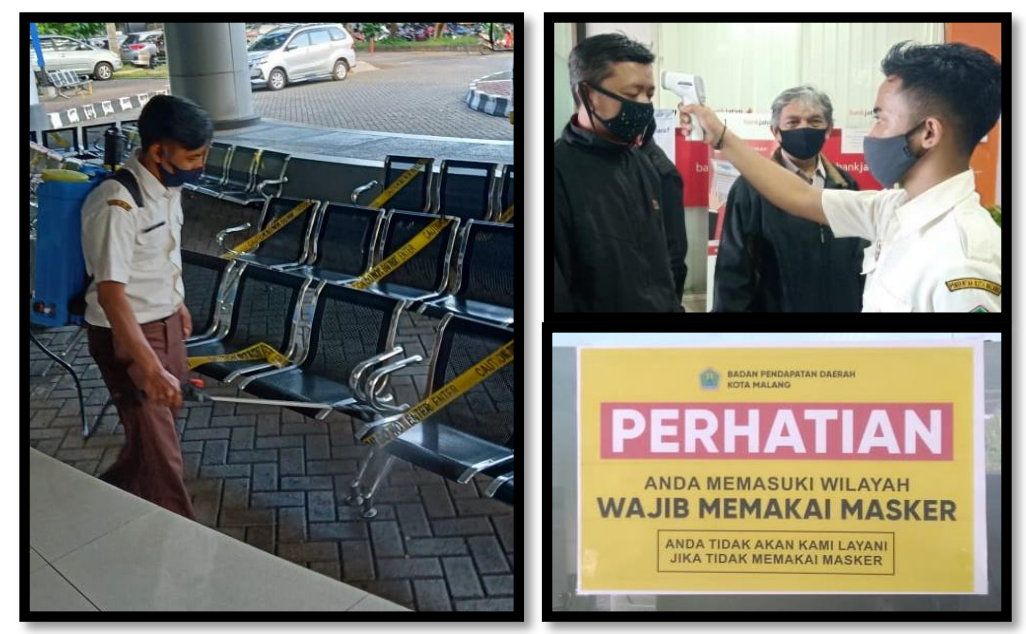

Sumber: Dokumentasi Penelitian, Juli 2020

Gambar 9. Pengurangan Pegawai yang Melayani dari Kapasitas Biasanya, Pemindahan Ruang Tunggu dari Dalam Ruangan ke Teras Bapenda, serta Pelayanan Mobil Bank Jatim dan Mobil $e$-tax
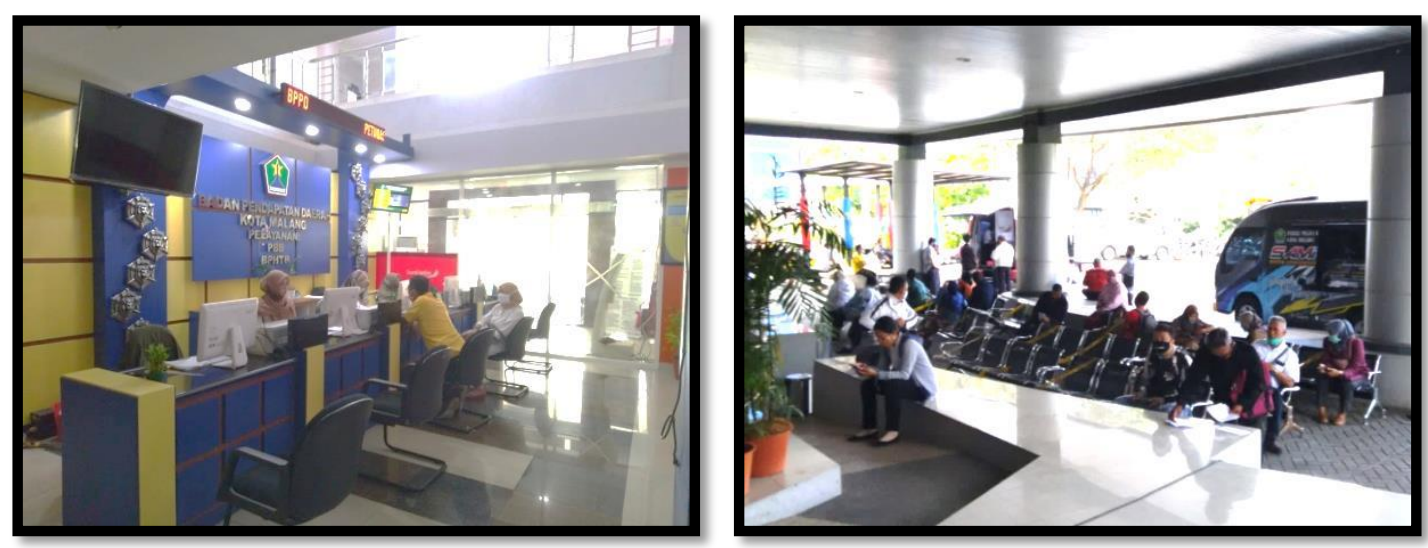


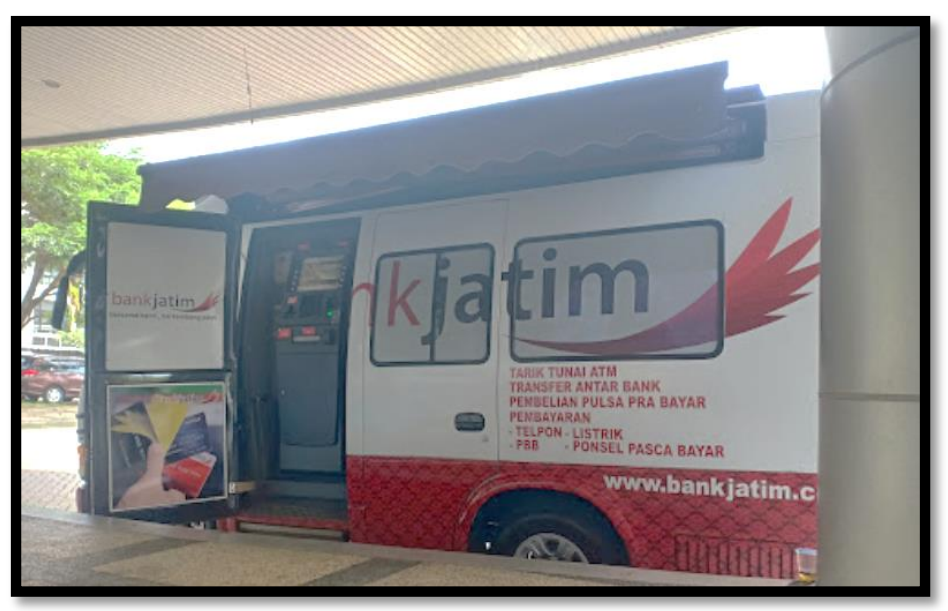

Sumber: Dokumentasi Penelitian, Juli 2020

Kompetensi petugas pemberi layanan, kompetensi petugas pemberi layanan juga sangat berpengaruh terhadap kualitas pelayanan. Beberapa tahun sebelumnya, pegawai yang ditempatkan di loket pelayanan adalah Non PNS atau pegawai TPOK. Namun berdasarkan evaluasi kerja yang dilakukan, maka penempatan pegawai di loket pelayanan harus berasal dari pegawai ASN sebagai penanggungjawabnya, sedangkan TPOK hanya sebagai pendukung atau membantu kerja ASN dalam kelancaran jalannya pelayanan. Selain itu, petugas di bagian loket juga dipilih berdasarkan kemampuan dan pengalaman kerja serta kemampuan dalam melayani wajib pajak.

\section{Permasalahan yang Dihadapi Di Masa Transisi New Normal}

Permasalahan yang dihadapi oleh Bapenda Kota Malang ini sebenarnya lebih pada kesadaran masayarakat akan pentingnya mematuhi protokol kesehatan. Karena tidak jarang, masyarakat ini bertindak abai. Seperti: 1) Malas mencuci tangan meskipun sudah diarahkan ke area wastafel untuk mencuci tangan, 2) Saat menunggu panggilan sesuai antrian, terkadang tidak duduk di tempat yang sudah disediakan malah bergerombol sehingga menimbulkan kerumunan, 3) bahkan ada yang melepas masker (menurunkan masker ke dagu) saat menunggu di kursi tunggu dengan alasan tidak nyaman untuk bernapas.

\section{PENUTUP}

Berdasarkan hasil dan pembahasan di atas dapat disimpulkan bahwa standar pelayanan publik di era transisi new normal yang dilakukan oleh Bapenda Kota Malang mengalami relaksasi untuk menyesuaikan dengan protokol kesehatan. 1) Prosedur Pelayanan dan Jangka Waktu Layanan, dilakukan dengan mengurangi pegawai yang bertugas di loket pelayanan dan mengalihkan pelayanan pelaporan serta konsultasi pajak melalui online, 2) Masyarakat tidak dipungut biaya dalam mengakases pelayanan, 3) Produk layanan telah tersedia dalam bentuk buku atau menanyakan langsung kepada petugas yang ada di ruang tunggu, 4) Sarana dan Prasarana untuk kesiapan pelayanan dengan protokol kesehatan telah dipenuhi dan 5) Petugas di bagian loket juga dipilih berdasarkan kompetensi dan pengalaman kerja dalam melayani 
wajib pajak. Sedangkan permasalahan yang dihadapi Bapenda adalah pada kesadaran wajib pajak untuk mematuhi protokol kesehatan yang ada.

\section{DAFTAR PUSTAKA}

Keputusan Mendagri (Kepmendagri) No. 440-830 Tahun 2020 tentang Pedoman Tatanan Normal Baru bagi Pemerintah Daerah (Pemda) dan Aparatur Sipil Negara (ASN) di lingkungan Kementerian Dalam Negeri (Kemdagri).

Lumbanraja, A. D. (2020). Urgensi Transformasi Pelayanan Publik melalui E-Government Pada New Normal dan Reformasi Regulasi Birokrasi. Administrative Law \& Governance Journal, 3(2), 220-231.

Mukarom, Z., \& Laksana, M. W. (2015). Manajemen Pelayanan Publik. Bandung: Pustaka Setia.

Mukarom, Z., \& Laksana, M. W. (2018). Membangun Kinerja Pelayanan Publik. Bandung: Pustaka Setia.

Mungkasa, O. (2020). Bekerja dari Rumah (Working From Home/WFH): Menuju Tatanan Baru Era Pandemi COVID 19. The Indonesian Journal of Development Planning, 4(2), 126-150.

Rohman, A. (2018). Dasar-dasar Manajemen Publik. Malang: Intrans Publishing.

Rohman, A., \& Trihardianto, W. T. (2019). Reformasi Birokrasi dan Good Governance. Malang: Intrans Publishing.

Sugiyono. (2018). Metode Penelitian Kombinasi (Mixed Scanning). Bandung: Alfabeta

Surat Edaran (SE) Wali Kota Malang No. 20 Tahun 2020 tentang Tatanan Normal Baru Produktif dan Aman Covid-19 bagi Aparatur Sipil Negara dan Karyawan/Karyawati BUMD.

Surat Edaran Menteri Pendayagunaan Aparatur Negara dan Reformasi Birokrasi (PANRB) No. 58/2020 tentang Sistem Kerja Pegawai ASN dalam Tatanan Normal Baru

Surat Edaran Walikota Malang Nomor 24 Tahun 2020 tentang perubahan atas Surat Edaran Walikota Malang Nomor 20 Tahun 2020 tentang Tatanan Normal Baru Produktif dan Aman Covid-19.

Taufik, T., \& Warsono, H. (2020). Birokrasi Baru Untuk New Normal: Tinjauan Model Perubahan Birokrasi Dalam Pelayanan Publik Di Era Covid-19. Dialogue: Jurnal Ilmu Administrasi Publik, 2(1), 1-18.

Undang-Undang Republik Indonesia Nomor 25 tahun 2009 tentang Pelayanan Pubik.

Yulianto, Y. (2020, July). Meningkatkan Kompetensi Aparatur Sipil Negara Dalam Pelayanan Publik Menuju Era New Normal. In Prosiding Seminar STIAMI (Vol. 7, No. 2, pp. 36-45). 